\title{
PENGGUNAAN MODEL PEMBELAJARAN CONTRUCTIVIST TEACHING SEQUENCESS (CTS) UNTUK MENINGKATKAN PEMAHAMAN SISWA DI KELAS V MI AL FATH KENDARI
}

\author{
Ibro Sutyono ${ }^{1)}$, Rimba Hamid ${ }^{2)}$, Amiruddin B. ${ }^{2)}$ \\ ${ }^{1)}$ MI Al Fath, Kendari, Indonesia \\ ${ }^{2)}$ Jurusan PGSD, Universitas Halu Oleo, Kendari, Indonesia \\ email:Ibrosutyono078@gmail.com
}

\begin{abstract}
Abstrak: Penelitian ini bertujuan untuk mengetahui peningkatan pemahaman siswa tentang konsep panas dan perpindahannya di kelas V MI Al-Fath Kendari. Jenis penelitian ini adalah Penelitian Tindakan Kelas (PTK), dan yang menjadi subjek penelitian adalah siswa yang aktif dan terdaftar pada semester genap tahun ajaran 2018/2019 kelas V MI Al-Fath Kendari, dengan jumlah siswa 26 orang. Penelitian ini dilakukan sebanyak dua siklus, setiap siklusnya terdiri dari dua kali pertemuan. Data dalam penelitian ini diperoleh dengan menggunakan tes pemahaman konsep. Hasil penelitian menunjukkan adanya peningkatan pemahaman konsep dari siklus I ke siklus II, dengan persentase ketuntasan 53,84\% dengan rata-rata 63,38 pada siklus I menjadi $88,46 \%$ dengan rata-rata 83,65 pada siklus II. Dengan demikian penggunaan model pembelajaran Contructivist Teaching Sequencess dapat meningkatkan pemahaman siswa tentang konsep panas dan perpindahannya di kelas V MI Al-Fath Kendari.
\end{abstract}

Kata Kunci: pembelajaran; konsep; siklus

\section{USE OF THE CONSTRUCTIVISTS TEACHING LEARNING MODEL SEQUENCESS (CTS) TO IMPROVE STUDENT COMPREHENSION CONCEPT IN CLASS VMI AL FATH KENDARI}

\begin{abstract}
This study aims to determine the increase in students' understanding of the concept of heat and its displacement in class V MI Al-Fath Kendari. This type of research is Classroom Action Research (CAR), and the subject of the study are active students who are registered in the even semester of 2018/2019 academic year class V MI Al-Fath Kendari, with 26 students. This research was conducted in two cycles, each cycle consisting of two meetings. Data in this study were obtained using concept understanding tests. The results showed an increase in understanding of the concept from cycle I to cycle II, with a percentage of completeness $53.84 \%$ with an average of 63.38 in the first cycle to $88.46 \%$ with an average of 83.65 in the second cycle. Thus the use of constructivist teaching sequencing learning models can improve students' understanding of the concept of heat and its displacement in class V MI Al-Fath Kendari.
\end{abstract}

Keywords: learning; concepts; cycles 


\section{Pendahuluan}

Dalam dunia pendidikan seorang guru memiliki peran yang sangat penting dalam meningkatkan mutu pendidikan di Indonesia. Sehingga guru dituntut untuk dapat mengembangkan potensi yang dimiliki serta mengikuti perkembangan konsep-konsep baru dalam dunia pendidikan. Karena menurut (Afrilianto, 2017:3) bahwa peran guru sangat penting untuk memotivasi siswa agar optimal belajar. Hal ini sejalan dengan pendapatnya (Wahyudi, 2014:1) bahwa guru atau pendidik merupakan ujung tombak pendidikan, karena guru memegang peranan yang cukup penting baik dalam perencanaan maupun pelaksanaan kurikulum.

Guru dikatakan sebagai tenaga pendidik yang professional jika guru menguasai keterampilan mengajar. Karena menurut (Saud, 2010:55-56), bahwa dalam mengajar diperlukan keterampilan-keterampilan yang dibutuhkan utntuk kelancaran proses belajar mengajar secara efektif dan efisien, keterampilan mengajar tersebut adalah sebagai berikut: a.) keterampilan membuka dan menutup pelajaran; b) keterampilan menjelaskan; c) keterampilan bertanya; keterampilan memberikan penguatan; d) keterampilan menggunakan media pembelajaran; $\quad$ e) keterampilan membimbing diskusi kelompok kecil; f) keterampilan mengelola kelas; g) keterampilan mengadakan variasi; dan h) keterampilan mengajar perorangan dan kelompok kecil.

Ilmu Pengetahuan Alam (IPA) sangat erat kaitannya dengan alam sekitar dan kehidupan sehari-hari. Hal ini senada dengan ungkapan dari (Samatowa, 2016:19) bahwa secara sederhana IPA didefinisikan sebagai ilmu pengetahuan yang mempelajari tentang gejala-gejala alam. IPA juga merupakan bagian dari ilmu pengetahuan yang terdiri dari faktafakta, konsep-konsep, prinsip-prinsip, dan teori-teori yang merupakan produk dari proses ilmiah.

Menurut Samatowa (Samatowa, 2016:56-57) dalam usaha meningkatkan kualitas pembelajaran Ilmu Pengetahuan Alam (IPA) maka akhir-akhir ini para ahli mengembangkan berbagai model pembelajaran yang dilandasi pandangan konstruktivisme dari Piaget. Dengan pandangan ini siswa akan membangun pengetahuannya sendiri, karena siswa tidak datang dalam keadaan kosong. Artinya adalah siswa sudah memiliki pengetahuan awal yaitu pengalaman siswa itu sendiri.

Kontruktivisme adalah epistemology pembelajaran bermakna dimana pembuatan teori yang menawarkan penjelasan tentang sifat pengetahuan dan bagaimana manusia belajar. Salah satu model pembelajaran yang menggunakan paradigma sebagai landasan konstruktivisme adalah model pembelajaran Constructivist Teaching Sequences (CTS). Dimana model pembelajran ini merupakan model pembelajaran yang cukup efektif dalam mengidentifikasi proses perubahan konseptual pada siswa. Constructivist Teaching Sequences (CTS) adalah cara guru mengetahui konsepsi siswa ketika mengembangkan konsep fisik, dan atau ketertarikan perilaku dan kebutuhan siswa secara eksplisit (Hamid, 2018:170).

Menurut (Nurmaliah, 2014:24) pemahaman konsep merupakan salah satu hasil belajar siswa dalam pembelajaran menggunakan proses berfikir menyangkut aktivitas otak. Selanjutnya menurut Bloom dalam (Wiguna, Nursid Sumaatmadja, 2013:31) berpendapat bahwa Pemahaman konsep merupakan kemampuan menangkap arti dari materi, seperti mampu mengungkapkan suatu materi yang disajikan ke dalam bentuk yang lebih dipahami, dan memberikan interpretasi dengan kata-kata sendiri. Proses pemahaman terjadi karena adanya kemampuan menjabarkan materi atau bahan ke materi lain. Pemahaman juga dapat ditunjukkan dengan kemampuan memperkirakan kecenderungan, kemampuan meramalkan akibat-akibat dari berbagai penyebab suatu gejala.

Menurut Pickard dalam (Rusdiana, Tawil, 2011:110) bahwa pemahaman konsep merupakan kemampuan menangkap makna dan arti dari materi pelajaran yang dipelajari oleh 
peserta didik. Hal ini sejalan dengan pendapat Sanjaya dalam (Ulia, 2010:57-58) bahwa pemahaman konsep adalah kemampuan siswa yang berupa penguasaan sejumlah materi pelajaran, dimana siswa tidak sekedar mengetahui atau mengingat sejumlah konsep yang dipelajari, tetapi mampu mengungkapan kembali dalam bentuk lain yang mudah dimengerti, memberikan interprestasi data dan mampu mengaplikasikan konsep yang sesuai dengan struktur kognitif yang dimilikinya.

Dari beberapa definisi tersebut dapat dimaknai bahwa pemahaman konsep adalah kemampuan siswa dalam memahami inti dari materi yang dipelajari dan mampu menjelaskan inti dari materi tersebut dengan menggunakan kata-katanya sendiri, serta mampu menghubungkan atau mengaitkan dengan kondisi yang ada pada saat sekarang ini.

Berdasarkan wawancara dan observasi di atas, penulis menyimpulkan bahwa guru kelas V MI Al-Fath Kendari lebih berpengalaman dalam hal mengajar dalam kelas dibandingkan dengan peneliti sebagai calon guru. Akan tetapi, guru perlu melakukan upaya perbaikan proses belajar mengajar agar kemampuan pemahaman konsep siswa meningkat. Hal ini dapat dilakukan dengan pemilihan metode, teknik, pendekatan ataupun model pembelajaran yang memudahkan tugas seorang guru dalam menerapkan materi ajar secara baik sehingga tujuan pembelajaran akan dicapai secara optimal. Salah satu model pembelajaran yang dapat menggantikan kegiatan percobaan dalam belajar mengajar yaitu model pembelajaran CTS.

Berdasarkan masalah yang telah dipaparkan sebelumnya, penulis sangat tertarik untuk mengadakan penelitian dengan judul "Penggunaan Model Pembelajaran Constructivist Teaching Sequences (CTS) untuk Meningkatkan Pemahaman Siswa tentang Konsep Panas dan Perpindahannya di Kelas V MI Al-Fath Kendari”.

\section{Metode}

Jenis penelitian ini adalah Penelitian Tindakan Kelas (PTK) yang dilaksanakan sebanyak 2 siklus. Setiap siklus dalam penelitian ini dilaksanakan dengan tahapan perencanaan (planning), pelaksanaan tindakan (action), observasi dan evaluasi (observation and evaluation), dan refleksi (reflection).

Penelitian ini yang telah dilaksanakan pada semester genap tahun pelajaran 2018/2019 bertempat di MI Al-Fath Kendari. Subjek penelitian ini adalah siswa yang aktif dan terdaftar pada semester genap tahun ajaran 2018/2019 di kelas V MI Al-Fath Kendari, dengan jumlah siswa 26 orang, masing-masing terdiri dari 12 orang laki-laki dan 14 orang perempuan. Adapun faktor yang telah diteliti dalam penelitian ini adalah: Faktor pemahaman siswa tentang konsep panas dan perpindahannya. Sumber data yang digunakan pada penelitian ini adalah informan, yaitu guru dan siswa kelas V SD MI Al-Fath Kendari.

Data dalam penelitian ini dianalisis secara kualitatif dan kuantitatif. Indikator keberhasilan dalam penelitian tindakan ini adalah pemahaman konsep siswa tentang konsep panas dan perpindahannya, siswa dikatakan telah memahami konsep yang diajarkan apabila meningkatnya penguasaan siswa yang ditandai dengan meningkatnya hasil belajar dengan batas minimal $75 \%$ siswa yang mencapai nilai $\mathrm{KBM} \geq 75$.

\section{Hasil}

Hasil penelitian menunjukkan bahwa terdapat peningkatan pemahaman siswa tentang konsep panas dan perpuindahannya di kelas $\mathrm{V}$ baik pada skenario pembelajaran maupun pemahaman siswa.

Berdasarkan hasil observasi aktivitas belajar siswa selama kegiatan pembelajaran pada siklus I dan II baik itu pertemuan I dan pertemuan II dapat dilihat secara lebih jelas ditunjukkan pada Tabel berikut: 


\section{Tabel 1 Analisis Data Aktivitas Belajar Kelompok Siswa Siklus I Pertemuan I}

\begin{tabular}{ccccccc}
\hline No & Uraian & K1 & K2 & K3 & K4 & K5 \\
\hline 1 & Skor Perolehan & 23 & 19 & 20 & 20 & 20 \\
\hline 2 & Skor Maksimal & & 32 & \\
\hline 3 & Persentase $(\%)$ & 72 & 59,37 & 62,5 & 62,5 & 62,5 \\
\hline 4 & Rata-rata & & 63,74 \\
\hline
\end{tabular}

Berdasarkan Tabel 1 di atas, terlihat bahwa persentase kelompok pada aktivitas belajar kelompok siklus I pertemuan 1 adalah kelompok 1 72\%, kelompok 2 59,37\%, kelompok 3 62,5\%, kelompok 4 62,5\% dan 62,5\% dengan rata-rata 63,72 dengan kategori cukup baik. Hal ini menunjukkan bahwa sebagian besar siswa tidak melaksanakan beberapa aspek kegiatan/aktivitas belajar kelompok siswa pembelajaran.

Adapun aktivitas siswa dalam proses pembelajaran pada siklus I pertemuan II dapat dilihat pada Tabel 2 berikut ini:

Tabel 2 Analisis Data Aktivitas Siswa Siklus I Pertemuan II

\begin{tabular}{ccccccc}
\hline No & Uraian & K1 & K2 & K3 & K4 & K5 \\
\hline 1 & Skor Perolehan & 24 & 22 & 22 & 21 & 23 \\
\hline 2 & Skor Maksimal & & 32 \\
\hline 3 & Persentase (\%) & 75 & 68,75 & 68,75 & 65,62 & 72 \\
\hline 4 & Rata-rata & \multicolumn{5}{c}{70,02} \\
\hline
\end{tabular}

Berdasarkan hasil observasi pada Tabel 2 juga menunjukkan bahwa aktivitas belajar kelompok siswa pada proses pembelajaran belum terlaksana dengan baik. Hal ini dapat dilihat pada persentase aktivitas belajar kelompok adalah kelompok $175 \%$, kelompok $268,75 \%$, kelompok 3 68,75\%, kelompok 4 65,62\% dan kelompok 5 72\% dengan rata-rata 70,02.ratarata aktivitas belajar siswa pada siklus I pertemuan II sebesar 70,02 dengan kategori baik. berikut ini:

Hasil observasi aktivitas siswa siklus II pertemuan I dapat dilihat pada Tabel 3

Tabel 3 Analisis Data Aktivitas Siswa pada Siklus II Pertemuan I

\begin{tabular}{ccccccc}
\hline No & Uraian & K1 & K2 & K3 & K4 & K5 \\
\hline 1 & Skor Perolehan & 26 & 24 & 25 & 24 & 24 \\
\hline 2 & Skor Maksimal & & \multicolumn{5}{c}{32} & \\
\hline 3 & Persentase (\%) & 81,25 & 75 & 78,12 & 75 & 75 \\
\hline 4 & Rata-rata & & 77,00 & & \\
\hline
\end{tabular}

Berdasarkan Tabel 3 di atas, terlihat persentase aktivitas belajar kelompok pada siklus I pertemuan 1 adalah kelompok 1 81,25\%, kelompok 2 75\% kelompok 3 78,12\%, kelompok 4 75\% dan kelompok 5 75\% dengan bahwa rata-rata 77 dengan kategori sangat baik. Hal ini menunjukkan bahwa sebagian besar siswa telah melaksanakan aspek-aspek kegiatan/aktivitas dalam pembelajaran.

Adapun aktivitas siswa dalam proses pembelajaran pada siklus II peretmuan II dapat dilihat pada Tabel 4 berikuti ini: 
Tabel 4 Analisis Data Aktivitas Siswa Siklus II Pertemuan II

\begin{tabular}{ccccccc}
\hline No & Uraian & K1 & K2 & K3 & K4 & K5 \\
\hline 1 & Skor Perolehan & 29 & 27 & 27 & 28 & 27 \\
\hline 2 & Skor Maksimal & & \multicolumn{3}{c}{32} \\
\hline 3 & Persentase $(\%)$ & 90,62 & 84,37 & 84,37 & 87,5 & 84,37 \\
\hline 4 & Rata-rata & \multicolumn{5}{c}{86,24} \\
\hline
\end{tabular}

Berdasarkan data pada Tabel 4, terlihat bahwa persentase aktivitas belajar kelompok pada pertemuan kedua persentasenya adalah kelompok $190,62 \%$, kelompok $284,37 \%$, kelompok 3 84,37\%, kelompok 4 87,5\% dan kelompok $584,37 \%$ dengan rata-rata 86,24 dengan kategori sangat baik. Hal ini menunjukkan bahwa hampir sebagian besar siswa telah melaksanakan aspek-aspek kegiatan/aktivitas belajar kelompok. Hal tersebut menunjukkan bahwa adanya peningkatan yang dilakukan oleh siswa pada setiap pertemuan baik siklus I maupun siklus II.

Berdasarkan hasil observasi aktivitas mengajar guru selama kegiatan pembelajaran pada siklus I dan II baik itu pertemuan I dan pertemuan II dapat dilihat secara lebih jelas ditunjukkan pada Tabel berikut:

Hasil observasi aktivitas guru pada siklus I pertemuan I dapat dilihat dipada Tabel 5 berikut ini:

\section{Tabel 5 Analisis Data Aktivitas Guru Siklus I Pertemuan I}

\begin{tabular}{ccc}
\hline No. & Uraian & Jumlah \\
\hline 1. & $\sum$ Jumlah Skor yang diperoleh & 29 \\
\hline 2. & $\sum$ Skor maksimal & 40 \\
\hline & Persentase $(\%)$ & $72,5 \%$ \\
\hline
\end{tabular}

Perolehan skor aktivitas mengajar guru pada siklus I pertemuan I adalah 72,5\% dengan kategori baik.

Adapun aktivitas guru dalam pelaksanaan pembelajaran pada siklus I pertemuan II dapat dilihat pada Tabel 6 berikut:

\section{Tabel 6 Analisis Data Aktivitas Guru Siklus I Pertemuan II}

\begin{tabular}{ccc}
\hline No. & Uraian & Jumlah \\
\hline 1. & $\sum$ Jumlah skor yang diperoleh & 32 \\
\hline 2. & $\sum$ Skor maksimal & 40 \\
\hline & Persentase $(\%)$ & $80 \%$ \\
\hline
\end{tabular}

Perolehan skor aktivitas mengajar guru pada Siklus I Pertemuan II adalah $80 \%$ dengan kategori sangat baik.

Hasil observasi aktivitas guru pada siklus II pertemuan I dapat dilihat pada Tabel 7 berikut ini:

Tabel 7 Analisis Data Aktivitas Guru Siklus II Pertemuan I

\begin{tabular}{ccc}
\hline No. & Uraian & Jumlah \\
\hline 1. & $\sum$ Jumlah skor yang diperoleh & 35 \\
\hline 2. & $\sum$ Skor maksimal & 40 \\
\hline & Persentase $(\%)$ & $87,5 \%$ \\
\hline
\end{tabular}


Berdasarkan data pada Tabel 7, terlihat bahwa perolehan skor aktivitas mengajar guru pada siklus II pertemuan I adalah 87,5\% dengan kategori sangat baik. Hal ini menunjukkan bahwa hampir sebagian besar aspek-aspek kegiatan/aktivitas dalam pembelajaran telah dilaksanakan guru. Adapun aktivitas guru dalam proses pembelajaran pada siklus II pertemuan II dilihat pada Tabel 8 ini:

Tabel 8 Analisis Data Aktivitas Guru Siklus II Pertemuan II

\begin{tabular}{ccc}
\hline No. & Uraian & Jumlah \\
\hline 1. & $\sum$ Jumlah skor yang diperoleh & 38 \\
\hline 2. & $\Sigma$ Skor maksimal & 40 \\
\hline & Persentase (\%) & $95 \%$ \\
\hline
\end{tabular}

Berdasarkan data Tabel 8, terlihat bahwa perolehan skor aktivitas mengajar guru pada siklus II pertemuan II adalah 95\% dengan kategori sangat baik. Hal ini menunjukkan bahwa hampir seluruh aspek-aspek kegiatan/aktivitas dalam pembelajaran telah dilaksanakan guru.

\section{Pembahasan}

Setelah materi yang diajarkan pada siklus I tentang materi sumber energi panas dan perbedaan suhu dan panas, maka kegiatan selanjutnya yang dilaksanakan ialah mengevaluasi.

Profil ketuntasan nilai tes siklus I dilihat pada Gambar 1 berikut ini:

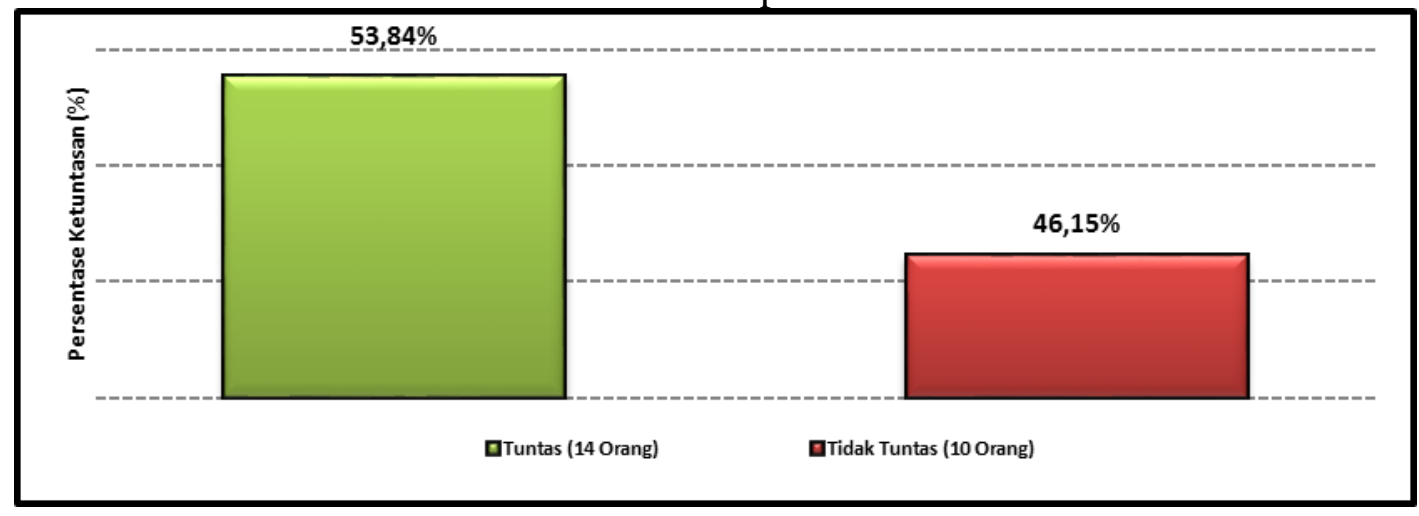

\section{Gambar 1 Diagram Persentase Siswa yang Mengalami Ketuntasan Belajar ada Tes Siklus I}

Berdasarkan hasil evaluasi pada siklus I, diketahui bahwa dari 26 orang siswa yang hadir pada tes siklus I, sebanyak 14 orang siswa memperoleh nilai $\geq 75$ dan dinyatakan telah mencapai ketuntasan belajar, sedangkan 12 orang siswa lainnya memperoleh nilai dibawah 75 dan dinyatakan belum tuntas. Dari perolehan nilai tersebut maka ketuntasan belajar siswa pada siklus I sebesar 53,84\% dengan rata-rata 65,38 sedangkan penelitian ini dikatakan berhasil jika evaluasi siklus siswa yang memperoleh nilai 75 adalah sebanyak $75 \%$. 
Profil ketuntasan nilai tes siklus II dapat dilihat pada Gambar 2 berikut ini:

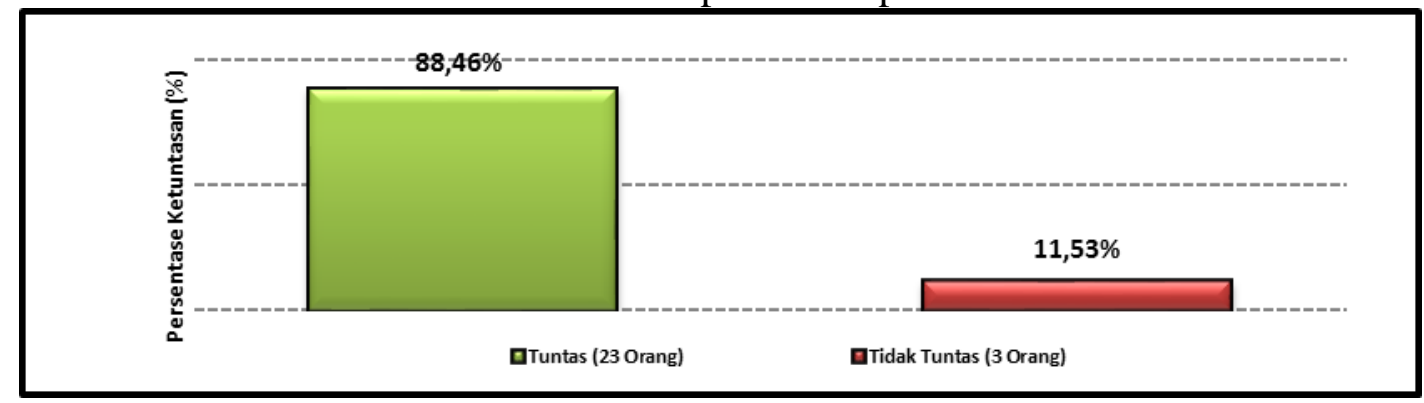

\section{Gambar 2 Diagram Persentase Siswa yang Mengalami Ketuntasan Belajar pada Tes Siklus II}

Berdasarkan hasil evaluasi pada siklus II, diketahui bahwa dari 26 orang siswa yang mengikuti tes siklus II, sebanyak 23 orang siswa yang memperoleh nilai $\geq 75$ dan dinyatakan telah mencapai ketuntasan belajar minimal (KBM), sedangkan 3 orang siswa lainnya memperoleh nilai dibawah 75 dan dinyatakan belum tuntas. Dari perolehan nilai tersebut maka ketuntasan belajar siswa pada siklus II sebesar 88,46\% dengan nilai rata-rata 83,65. Hal tersebut menunjukkan bahwa peneliti telah mencapai target yaitu indikator keberhasilan $75 \%$.

Penelitian ini menggunakan model pembelajaran CTS pada konsep panas dan perpindahannya. CTS merupakan strategi pembelajaran aktif yang dalam pelaksanaannya menuntut siswa untuk terlibat aktif selama proses belajar mengajar. Model pembelajaran CTS dalam hal ini dapat membantu siswa untuk mempermudah memahami konsep-konsep yang ada dalam materi dengan keterampilan siswa menjadi lebih mengerti konsep-konsep yang ada sekaligus arti hubungan antar konsep yang ditemukannya. Sehingga dari uraian tersebut membuktikan bahwa dengan menggunakan model pembelajaran CTS bukan hanya pemahaman konsep siswa saja yang meningkat melainkan aktivitas mengajar guru dan aktivitas belajar siswa pada tema panas dan perpindahannya kita di kelas V MI Al-Fath Kendari.

\section{Simpulan}

Berdasarkan hasil penelitian dan pembahasan maka dapat disimpulkan bahwa:

1. Penggunaan model pembelajaran CTS dapat meningkatkan pemahaman konsep siswa kelas V MI Al-Fath kendari, yakni hasil belajar siswa siklus I dengan persentase ketuntasan 53,84\% dengan nilai rata-rata 63,38 meningkat pada siklus II yakni hasil belajar siswa mencapai presentase ketuntasan 88,46\% dengan nilai rata-rata 83,65.

2. Persentase aktivitas guru dalam proses pembelajaran siklus I pertemuan pertama sebesar 72,5\% dan pertemuan kedua sebesar $80 \%$ sedangkan pada siklus II pertemuan pertama sebesar $87,5 \%$ dan pertemuan kedua sebesar $95 \%$.

3. Pengamatan aktivitas belajar kelompok siswa dalam mengikuti proses pembelajaran siklus I pertemuan pertama dengan rata-rata 63,74 dan pertemuan kedua 70,02 sedangkan pada siklus II pertemuan pertama dengan rata-rata 77,00 dan pertemuan kedua 86,24 . 


\section{Referensi}

Afrilianto, H. H. (2017). Langkah Praktis Penelitian Tindakan Kelas Bagi Guru. Bandung: PT Refika Aditama.

Hamid, R. (2017). Analisis Learning Progression Siswa Pada Pembelajaran Listrik Dan Magnet Dengan Model Constructivist Teaching Sequences (CTS). UPI. Universitas Pendidikan Indonesia.

Hamid, R. (2018). Katalisme dalam Pembelajaran Sains. Makassar: CV. Nas Media Pustaka.

Nurmaliah, S. I. dan E. A. (2014). Penggunaan Metode Karyawisata Untuk Meningkatkan Pemahaman Konsep Dan Keterampilan Proses Sains Pada Materi Keanekaragamanhayati, 2(1), 23-27.

Rusdiana, Tawil, D. (2011). Efektifitas Pembelajaran Berbasis Simulasi Komputer pada Topik Superposisi Gelombang untuk Meningkatkan Pemahaman Konsep Mahasiswa. Jurnal Sains dan Pendidikan Fisika, VII(2).

Samatowa, U. (2016). Pembelajaran IPA DI Sekolah Dasar. Jakarta: PT Indeks.

Saud, U. S. (2010). Pengembangan Profesi Guru. Bandung: Alfabeta.

Suharsimi Arikunto, S. dan S. (2017). Penelitian Tindakan Kelas. Jakarta: Bumi Aksara.

Sukardi. (2015). Metode Penelitian Pendidikan Tindakan Kelas Implementasi dan Pengembangannya. Jakarta: Bumi Aksara.

Ulia, N. (2010). Peningkatan pemahaman Konsep Matematika Materi bangun Datar dengan Pembelajaran Kooperatif Tipe Group Investigation dengan Pendekatan Saintifik Di SD. Jurnal Tunas Bangsa, III(2).

Wahyudi, I. (2014). Panduan Lengkap Administrasi Mengajar Guru. Jakarta: PT Prestasi Pustakarya.

Wiguna, Nursid Sumaatmadja, E. N. (2013). Pengaruh Model Pembelajaran POE Terhadap Pemahaman Konsep dan Kemampuan Berpikir Kreatif Peserta Didik. Jurnal Gea, $X I I(1)$. 